\title{
The Doha Round impasse: A graphical account
}

\author{
Simon J. Evenett
}

Published online: 27 May 2014

(C) Springer Science+Business Media New York 2014

\begin{abstract}
Several factors potentially responsible for the failure to conclude the Doha Round of multilateral trade negotiations are analyzed. A two-stage negotiation and ratification game between the "North" (industrialized countries) and the "South" (developing countries) is employed and collapses into a single diagram. The choice of negotiating agenda, principles, and currency of the Doha Round interact with domestic political factors in leading WTO members, the fast growth of exports prior to 2007, and pervasive unilateral trade reform to eliminate the "landing zone" for this particular multilateral negotiation. Recent emphasis on differences between developing countries and on Chinese WTO accession as independent causes of the impasse seems misplaced.
\end{abstract}

Keywords WTO $\cdot$ Doha Round $\cdot$ Deadlock $\cdot$ Impasse $\cdot$ Two-level games

JEL Classification $\mathrm{F} 02 \cdot \mathrm{F} 13 \cdot \mathrm{F} 53$

\section{Introduction}

Nearly every economic analysis of trade negotiations concerns those that have been concluded with an agreement to cut trade barriers. The emphasis, then, has tended to be on the rationale for trade agreements and the effects of their implementation. Far less

\footnotetext{
Many of the ideas in this paper have been presented at seminars and conferences across Europe starting in 2006, when the Doha Round negotiations appeared to me to be headed towards deadlock. I am grateful for the comments of participants at seminars at the World Trade Organization, CEPII, and the Graduate Institute in Geneva. These ideas have been presented at the 2013 PEIO conference in Heidelberg/Mannheim, at the Nordic International Trade Seminar (NOTIS) in 2008, and at a conference at the University of Cambridge titled "Breaking the Deadlock at Doha" in November 2006. Dozens of trade policy experts were consulted in the preparation of this paper often supplying useful papers, many of which are referenced here. I am grateful to all of these experts. Particular thanks to Bernard Hoekman, Marcelo Olarreaga, John Odell, Will Martin, Robert Wolfe, and the referees for comments on an April 2013 version of this paper.
}

S. J. Evenett $(\bowtie)$

SIAW-HSG, University of St. Gallen and CEPR, Bodanstrasse 8, 9000 St. Gallen, Switzerland e-mail: simon.evenett@unisg.ch 
attention has been given to what might be referred to as the "basis of the deal" (who gets what in return for what) and the factors conducive to bringing negotiations to a successful conclusion. ${ }^{1}$

This omission would be less glaring were it not for the fact that one of the most significant events in the multilateral trading system during the past 10 years has been the failure to conclude the Doha Development Agenda. This Agenda was formally launched in fraught circumstances at a WTO Ministerial meeting in November 2001, itself following a divisive meeting of WTO members in Seattle in 1999. While this round of multilateral trade negotiations was formally launched in 2001, it was not until after a WTO Ministerial meeting collapsed in Cancun in 2003 that the contents of the negotiating agenda could be agreed upon in mid2004 (in the so-called July Package.)

Some progress was then made in negotiations - notably with respect to the phasing out of agricultural export subsidies and, subsequently, trade facilitation measures - but as this negotiation is governed by a Single Undertaking, no obligations will come into effect until every related matter has been settled by the WTO membership. In fact, reaching a final accord has not been possible, with growing acrimony between leading WTO members since 2008, at that time over special provisions to protect farmers in developing countries and, more generally, over the appropriate degree of liberalization by different types of WTO members.

As of this writing, even though the odds of successfully concluding this negotiation have lengthened, no government has formally called for work on the Doha Development Agenda to cease. There appears to be no appetite among WTO members to bring these negotiations to a fruitful conclusion, nor to end them. Attempts to salvage parts of the negotiation have been rebuffed.

As this potted history shows, there have been several deadlocks in the Doha Round negotiations - with respect to the launch of the negotiation, setting the negotiating agenda, finalizing the negotiation with its original scope, and subsequently, finalizing parts of the original negotiating agenda. The subject matter of this paper is confined to the limited likelihood ${ }^{2}$ witnessed in recent years of concluding the Doha Round with its original scope. ${ }^{3}$ Three features characterize this particular impasse (a) the emergence of disagreement between leading jurisdictions after the negotiation commenced, ${ }^{4}$ (b) several failed

\footnotetext{
${ }^{1}$ Although the focus of this paper is on the Doha Round it is worth noting that in recent years it was not possible to conclude successfully the negotiation of several free trade agreements. Some negotiations failed outright (US-South Africa), some were never launched after initial discussions highlighted stumbling blocks (US-Switzerland), and other negotiations that were launched have dragged on and on with no end in sight (EU-Mercosur). Such instances might provide additional insights into the causes of failed trade negotiations. None of these cases, however, are on the scale of the Doha Development Agenda, perhaps limiting their relevance to the matters considered in this paper.

${ }^{2}$ Despite the use of words such as "likelihood" in the characterization of a negotiating impasse, the simple model presented in this paper is deterministic.

${ }^{3}$ My focus here is on the entire negotiation, not an element of it. There may well be particular reasons why some policies are less amenable to inclusion in legally binding international accords. Hoekman (2008) makes such a case for service sector regulations, negotiations concerning which have made very little progress in the Doha Round.

${ }^{4}$ The existence of disagreement alone may not indicate that the negotiation is doomed to failure. After all, it is well known that bargaining models where players face uncertainty over key parameters can endogenously induce delays.
} 
attempts $^{5}$ to resolve those differences (even if some narrowing of those differences has been observed ${ }^{6}$ ), and (c) the likelihood that future attempts will fail as well. Therefore a negotiation, that the parties presumably thought initially had some chance of success, is unlikely to be concluded on anything like the scale originally envisaged, if it is concluded at all. ${ }^{7}$ Implicit in this characterization is the suggestion that circumstances have arisen that were not anticipated when the negotiation began. Among others, two unanticipated factors will be emphasized in what follows.

Existing literature provides the rationale for several of the building blocks of the approach taken here. First, a two-stage process of international negotiation and then domestic ratification is employed, so that forward-looking negotiators keep an eye on the consequences of any concessions they make for the extent of domestic support for the potential final accord (Putnam 1988 more generally and, in the Doha Round context, Elsig and Dupont 2011). ${ }^{8}$ The approach taken here is designed so as to allow considerations pertinent to both stages of the game to be collapsed into a single diagram.

Second, I emphasize the "North-South" or "industrialized country versus developing country" dimension of the Doha Round negotiation, as do Bagwell and Staiger (2012), Blustein (2009), Hufbauer and Schott (2012a), Ismail (2012), and Schwab (2011), among others. ${ }^{9}$ The central matter here is the extent to which different classes of WTO members should make comparable contributions to the Doha Round package. This modelling choice does not imply that the "North" or the "South" were always cohesive coalitions. $^{10}$

Third, key features of the WTO are highlighted here, such as the widely (if not universally) held view that any Doha Round accord must adhere to the principle of Less Than Full Reciprocity (Lamy 2008; Bhagwati and Sutherland 2011). The importance of bindings as the negotiating currency of the WTO at a time when there are substantial differences between bound and applied policies-a factor emphasized by, among others, Young (2010) and by associations of American and European manufacturers-is considered as well.

Fourth, the inability to conclude an agreement is treated in a degenerate manner. I identify factors that frustrate ratification or that are incompatible with the widely accepted negotiating principles of the Doha Round. That is, in the language of

\footnotetext{
5 There has certainly been resort to "deadlines" that seek to induce movement by the parties, the very type of "action forcing" events that Narlikar (2010) refers to.

${ }^{6}$ For example, in 2008 the Director-General of the WTO claimed that $80 \%$ of the matters to be negotiated had been settled. Unfortunately, assuming that WTO members stick to their plan to conclude the negotiation as a Single Undertaking, it is necessary to agree on all matters. Even agreement on $99 \%$ of all matters is, in principle, not enough.

${ }^{7}$ There is no suggestion here that the three features of the current Doha Round impasse are similar to those deadlocks that took place earlier in the Doha Round, that were mentioned at the beginning of the paragraph in the main text.

${ }^{8}$ As former senior US trade diplomat Grant Aldonas has written "One of the great ironies of the international trading system is that it is really a question of grappling with domestic politics. That reality filters through to the basic way in which we bargain" (Aldonas 2007, page 31).

${ }^{9}$ Here I depart from Young (2010), who emphasizes the political considerations affecting the evaluation of Doha Round negotiating offers in the United States and the European Union.

${ }^{10}$ Page et al. (2008) document, for example, differences in the position of various groups of developing countries with respect to the contents of a "development package" for the Doha Round.
} 
international political economy research, I identify circumstances where no "win set" between the parties exists (Elsig and Dupont 2011).

Although the reception at home to an agreement negotiated with trading partners is given prominence in what follows, this does not deny the importance that domestic actors may attribute to economic considerations. ${ }^{11}$ In this regard, the demonstration by Bagwell and Staiger (2012) of the incompatibility of the goal expanding developing country exports with certain trade-offs in the negotiating set of the Doha Round is important as it calls into question what the Doha Round could ever achieve. Empirical analyses in recent years that reduced the estimated value of the trade and GDP created by extant Doha Round negotiating proposals have likely influenced the perception of policymakers in key jurisdictions as well (Anderson et al. 2009; Hufbauer et al. 2010; Decreux and Fontagné 2011; Martin and Mattoo 2011). ${ }^{12}$

Not every argument in the literature on the Doha Round is taken up in the analysis below, ${ }^{13}$ leaving plenty of room for further research. Harbinson (2012), for example, emphasizes a tactical mistake in allowing certain negotiations to drag on so that, with the passage of time, the original Doha Round negotiating agenda seemed less and less relevant. An IMF analysis noted "Consensus has been difficult to achieve partly because of changed geopolitical circumstances" (IMF 2011), language that is probably code for the fast growth of Chinese exports and output in the decade after the Doha Round was launched.

In his analysis of the public disagreement over agricultural safeguards in 2008 and of the July 2008 WTO ministerial meeting Wolfe (2009a, b) blames insufficient time to prepare ministers for difficult decisions rather than deeper policy choices, such as adherence to the Single Undertaking. ${ }^{14}$ In contrast, Hufbauer and Schott (2012b) argue the Single Undertaking is the "fatal flaw" of the Doha Round. Earlier they contended that the lack of progress in negotiating service sector reforms diminished industrial country interest in the Doha Round (Hufbauer and Schott 2012a). Bagwell and Staiger (2012) note that, for manufactured goods, at present industrialized countries maintain much lower tariffs than most developing countries and that the former are running out of negotiating coin.

The remainder of this paper is organized as follows. The next section introduces the model's two-stage structure and focuses on the factors affecting the domestic ratification stage and the degenerate notion of an impasse employed here. The third section

\footnotetext{
${ }^{11}$ Still, as Aldonas (2007) notes, "Although we know that trade is a two-way street, we bargain as if it is a oneway thoroughfare. Negotiators attempt to gain as much as possible for their export interests, while defending their politically sensitive industries from imports. In short, we take a non-zero-sum world and turn it into a zero-sum game" (page 7).

${ }^{12}$ In the years after the Doha Round was launched new data on the size of trade barriers became available for Computable General Equilibrium models and the resulting "headline" estimates of the gains from completing this multilateral trade negotiation fell (Ackerman and Gallagher 2008). In more recent years, more information on the degree of trade barrier adjustment by different types of WTO member implied by latter negotiating proposals led a further revision downward in the magnitude of the gains to the larger trading powers.

13 Tarullo (2006) is a prescient, early assessment of the difficulties in negotiating the Doha Development Agenda.

${ }^{14}$ Wolfe (2007) cannot conceive of the WTO without the Single Undertaking, arguing that it is inherent in the manner in which WTO members negotiate with one another. Hence, in his view, blaming the Single Undertaking for the Doha Round's travails misses the point.
} 
shows that the interaction between an important negotiating principle of the Doha Round and domestic political factors can generate impasses.

The fourth section considers the implications of domestic political changes in major industrialized countries that took place from 2006 on. The fifth section identifies factors that affected the outside options of the North and the South after the Doha Round was launched and before the global financial crisis reduced world trade in 2009. The sixth section shows that the use of bound policies rather than applied policies as the negotiating currency in the Doha Round can result in sustained unilateral trade reform becoming a stumbling block to concluding multilateral trade negotiations. Intra-South dynamics, including reactions to China's growing export prowess, are discussed in the seventh section. Concluding comments and policy implications are presented in section eight.

\section{A simple two-stage game that can generate impasses}

For the purposes of this paper, I take the Doha Round to be a negotiation between two countries, the North (an industrialized country) and the South (a developing country.) To further simplify matters, I assume that all of the complexity of national commercial policies can be collapsed into a single index which, for historical reasons only, I refer to as tariffs. A proposed Doha Round deal, then, is a pair of actual tariff cuts, which can be represented graphically as a point in the positive quadrant of $\mathrm{R}^{2}$.

The international negotiation takes place in stage one and domestic ratification is considered in stage two. Negotiators are forward-looking and, in the deterministic framework employed here, can see if a proposed deal is acceptable to enough domestic constituencies to be ratified. Reciprocal trade barrier reduction is assumed to hurt some domestic commercial interests and benefit others. Here national political systems, however constituted, aggregate the reactions of the winners and losers from any proposed Doha deal and determine whether or not a deal will be ratified.

I represent the political factors at work in the second stage by a ratification constraint (RC), see Fig. 1. For every potential tariff cut by the North, the minimum actual tariff cut by the South necessary to generate enough political support to get an accord with this pair of tariff cuts ratified in the North is established. Although the ratification constraint is drawn as convex in Fig. 1, in fact, the only assumption that seems reasonable is that such constraints be monotonic. That is, the minimum tariff cut by the South necessary to generate enough support in the North for ratification is assumed to be higher in potential Doha Round deals where the North cuts its own tariffs by more.

In Fig. 1 any pair of tariff cuts on or above the ratification constraint of the North is politically acceptable to the North. Points above the North's ratification constraint are associated with more tariff cuts by the South and therefore more gains to Northern commercial interests. A relaxation of the North's ratification constraint would involve shifting the constraint down vertically in Fig. 1.

In Fig. 1 the no agreement outcome is represented by the origin, point $(0,0)$. If the North's ratification constraint were to be drawn so as to cut the vertical axis above the origin, then, to induce a move away from the no-agreement status quo, it would imply that political factors in the North require that the South must agree to cut its tariffs by a 


\section{Represent domestic political factors with "ratification constraints" (RC)}

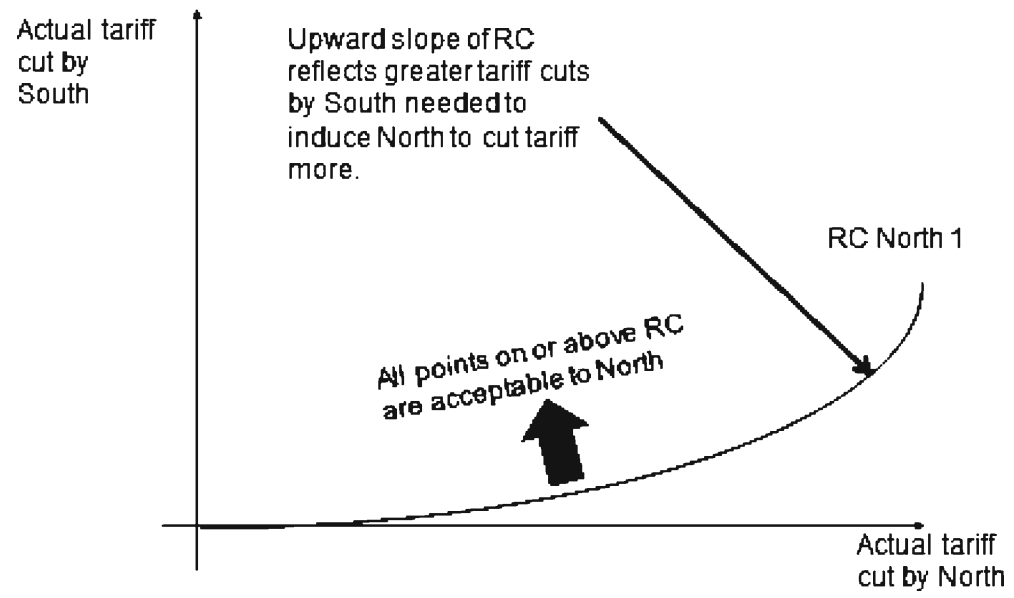

Fig. 1 Represent domestic political factors with "ratification constraints" (RC)

minimum, positive amount. The more attractive the status quo is - perhaps because the North's exports are growing faster independently of the multilateral trade negotiationthe larger will be this minimum tariff cut by the South (but more on this matter in section 5).

The calculus underlying the ratification constraint is as follows. Foreign commercial policy reform will benefit some domestic interests, who then lobby for ratification - in so doing, they oppose the losers from domestic commercial policy concessions in the negotiation. The extent to which the domestic government compensates losers through national tax and welfare systems undercuts opposition to the deal and may lower the minimum tariff cut expected of the trading partner, so relaxing the ratification constraint. The extent to which supply side failings at home and trade facilitation bottlenecks abroad limit the extent to which domestic interests can take advantage of foreign tariff cuts will increase domestic demands of their trading partner, represented graphically by a tightening of the ratification constraint at home. ${ }^{15}$

The political arrangements a jurisdiction has for considering trade deals can affect the ratification constraint. The Fast Track Authority conferred in the past by the US Congress on that nation's Federal Government is generally believed to have eased Congressional approval of trade agreements (Destler 2005). Therefore, the loss of that Authority during the Doha Round can be represented here as a tightening of the North's ratification constraint. Likewise, as a result of implementing the Treaty of Lisbon, the ratification of European Union trade deals by the European Parliament could cause the North's ratification constraint to shift vertically up.

Changes in the negotiating set after the formal negotiation began may alter ratification constraints as well. Suppose an item was added to the negotiation that benefits primarily the North's commercial interests. On the assumption that the negotiation on the new item is concluded successfully, should the North require less domestic commercial support for the remainder of the negotiating package, then the minimum tariff

$\overline{15}$ This opens the door for supply side reforms and Aid For Trade initiatives to shift the ratification constraint. 


\section{Ratification Constraints can allow for a "Landing Zone"}

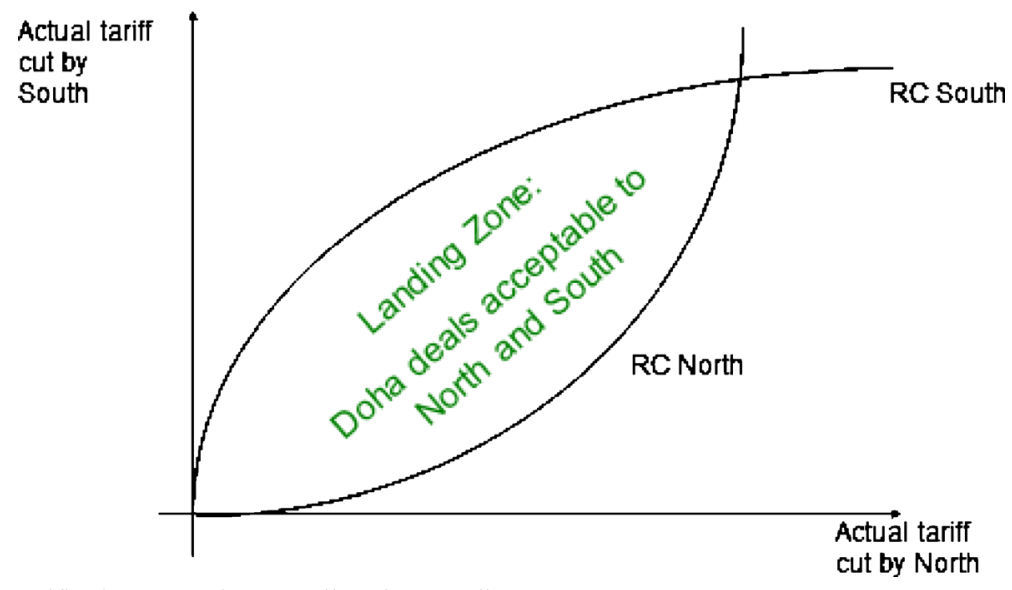

Fig. 2 Ratification constraints can allow for "Landing Zone"

cut that the North must demand of the South on the original items in the negotiating set is reduced, relaxing the North's ratification constraint. Such considerations may be of use in assessing proposals to add or drop negotiating items from the Doha Round.

Other than monotonicity of the ratification constraint, I do not put any more structure on the political process in the North and South than this. This has both a drawback and an advantage. The drawback is that this approach does not unpack the factors that determine the minimum tariff cut by the negotiating partner needed to secure ratification at home. The advantage of this approach is that monotonicity of ratification constraints may be a property of different types of political system. Therefore, this

An Impasse: No Landing Zone

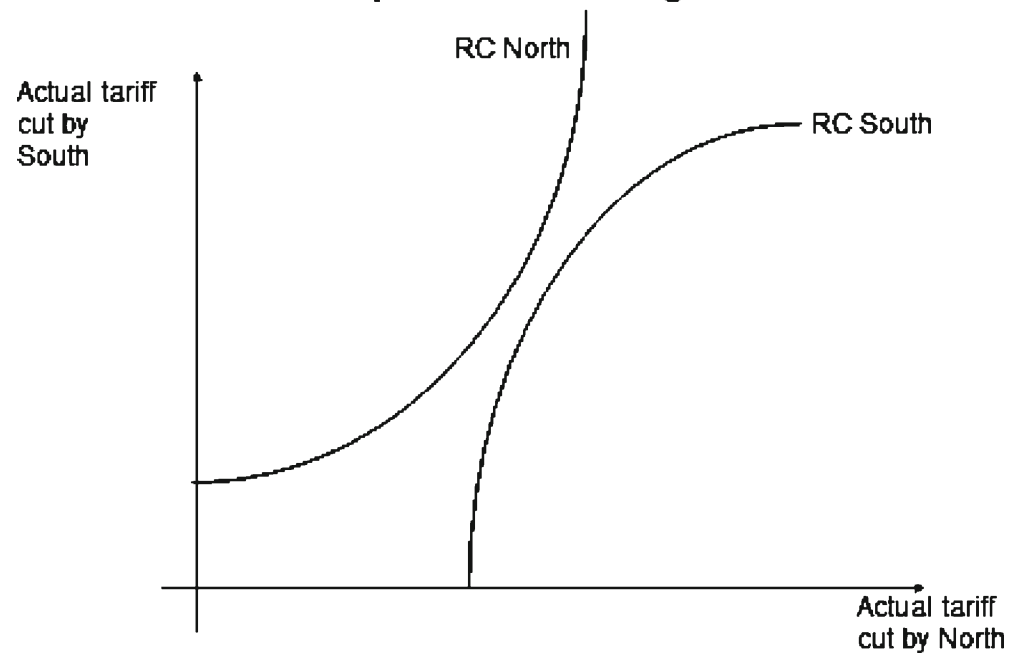

Fig. 3 An impasse: no landing zone 
analysis is not tied to any one particular model of the political economy of trade policy formation.

The ratification constraints of the North and South can be represented in the same diagram, as shown in Fig. 2. All of the points on or below the South's ratification constraint are politically viable in the South. Combining the North and South's ratification constraints reveals which, if any, tariff cutting deals negotiated in the first stage can survive the domestic ratification process in the second stage. Figure 2 reveals what some trade practitioners refer to as the "landing zone," namely, tariff cutting deals that meet both nations' ratification constraints. Since impasses are the focus of this paper, I invoke no further assumptions to determine which point in the landing zone is selected during the negotiation.

An impasse arises when there is no tariff cutting deal that satisfies simultaneously each nation's ratification constraint. Two ratification constraints that generate an impasse are drawn in Fig. 3. Thus, impasses are possible without invoking any of the features of the Doha Round. However, to make matters interesting, I start with the case the North and South's ratification constraints alone generate a landing zone. In what follows I add features that reduce - and in some cases - eliminate the set of potential Doha Round deals.

\section{The less than full reciprocity principle of the Doha Round}

When the Doha Development Agenda was launched in November 2001, considerable attention was given to the interests of developing countries. ${ }^{16}$ One tangible manifestation of this commitment was that developing countries would be expected to liberalize their trade regimes by less than industrialized countries. In the context of the negotiations on manufactured goods, this was enshrined in the Less Than Full Reciprocity Principle. ${ }^{17}$ Given that the differential treatment of industrialized and developing countries has become a particularly contentious matter, it is worth examining the implications for the landing zone of adopting this negotiating principle.

A further assumption must be made so as to represent that Principle graphically. At this stage, it is worth recalling that in a speech to parliamentarians in 2008, the DirectorGeneral of the WTO, noted ${ }^{18}$ :

"I hasten to add that all efforts in the Doha Round would have been made in accordance with the principle of Less than Full Reciprocity, with the developed world making $2 / 3 \mathrm{ds}$ of the contribution, and the emerging part of the developing world only $1 / 3 \mathrm{~d} . ”$

\footnotetext{
${ }^{16}$ The words "developed" and "developing" are littered throughout the November 2001 Ministerial Declaration that launched the Doha Development Agenda. See http://www.wto.org/english/thewto_e/minist_ e/min01 e/mindecl e.htm

${ }^{17}$ Subsequently, different groups of developing countries have been able to negotiate different levels of liberalization and in some instances, no reform is expected of certain categories of developing countries. Recall, also, that a WTO member can elect to have developing country status.

${ }^{18}$ See http://www.wto.org/english/news_e/sppl_e/sppl99_e.htm
} 
Suppose that the above statement is interpreted as requiring that the North cut its tariffs by at least twice the tariff cut of the South. ${ }^{19}$ On this interpretation, the Less Than Full Reciprocity Principle can be imposed as an additional constraint on the set of possible tariff cutting deals. Figure 4 shows the bite that this requirement has. Essentially, all of the tariff deals above the LTFR line violate this negotiating principle. The set of Doha Deals is necessarily restricted, but does an impasse result?

Not necessarily. As Fig. 5 shows, it is possible for some of the original landing zone to survive the imposition of a LTFR rule. However, with either a tighter LTFR rule (see Fig. 6) or a more restrictive Northern ratification constraint, the set of acceptable tariff deals can be eliminated. Indeed, in many of the figures that follow, the interaction between the Northern ratification constraint and the LTFR rule determines the outcome. The imposition of a negotiating principle, agreed at the beginning of this multilateral trade negotiation with the noble goal of skewing the eventual deal in the favor of developing countries, can in fact preclude such deals being concluded in the first place.

A few more comments on the LTFR rule are in order. First, if one objects to my characterization of this rule, then surely a necessary condition for a LTFR rule in tariff cutting space is that it lie below the $45^{\circ}$ line. If so, then this restricts the set of potential deals as well, but not in the same way.

Second, given the imposition of the LTFR limits the tariff benefits that the North can receive from Southern reform, then one might wonder why the North agreed to this Principle in the first place. One potential explanation is that developing countries may have made the acceptance of this Principle one of the "prices" that had to be paid for the launch of the Doha Round. Since many developing country officials appear to believe that their countries were short changed during the Uruguay Round of multilateral trade negotiation, then the adoption of this rule might have been seen as offering some reassurance as to the outcome of the Doha Round.

Third, once the restrictive nature of the LTFR rule became clear, questions must surely arise as to why the North continued to adhere to it and how the South was able to hold together its collective support for the rule. As to the former, the attempts by the United States later in the Doha Round to increase the contribution of the large emerging markets (through calls, for example, for the addition of a wide range of sectoral deals to eliminate tariffs) can be interpreted as an attempt to break free from the LTFR constraint. In doing so the US received some support from other industrialized countries, but many of the latter appeared less vexed by the development objectives of the Doha Round. Perhaps the latter industrialized countries worried that developing countries might walk away from the Doha Round negotiations should the Less Than Full Reciprocity Principle be abandoned.

\section{Declining support for trade reform in North and South}

It is striking that several analysts have pointed to reductions in public support for open borders and trade reform in certain leading jurisdictions from 2005. These shifts appear

\footnotetext{
${ }^{19}$ I accept that the quotation above could be interpreted in other ways. For examples, the contribution need not be the level of tariff cut, but the estimated increase in tariff volume or the extent to which tariff revenues are expected to fall. The latter two criteria were used to interpret the relative contributions of developing and industrialized economies during the previous multilateral trade negotiation, the Uruguay Round.
} 


\section{What bite does the LTFR requirement have?}

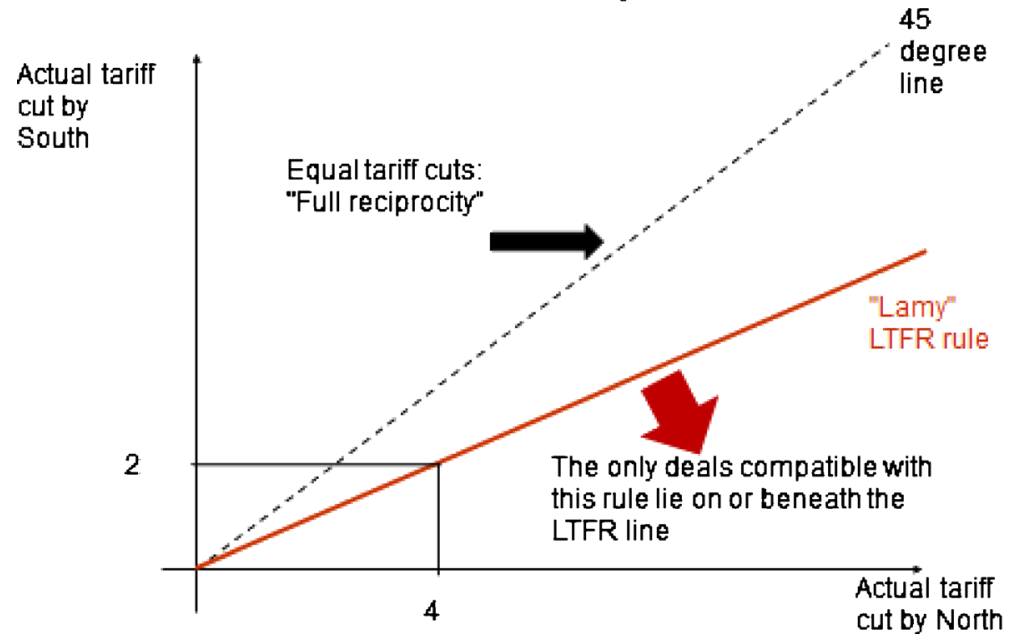

Fig. 4 What bite does the LTFR requirement have?

not to have been anticipated at the time of the launch of the Doha Round and, therefore, are likely to shift the ratification constraints of the North and the South.

Young (2010) documents some of the evidence of and factors responsible for the falling support for trade reform in the United States and in the European Union. In the US, the 2006 midterm Congressional election saw a number of pro-trade elected representatives replaced by persons more skeptical of trade reform (Evenett and Meier 2006). In addition, the lapsing of Fast Track Authority was said to have complicated the Congressional approval of trade deals (Tarullo 2006; Schwab 2011).

Horse trading in the Indian parliament to ensure a vote of confidence in that country's government is said to have implicated Indian commercial policies in 2008. Furthermore, having remained quiet during its first five years of WTO membership, from 2006 on China

\section{Combine ratification constraints and LTFR: a restricted landing zone}

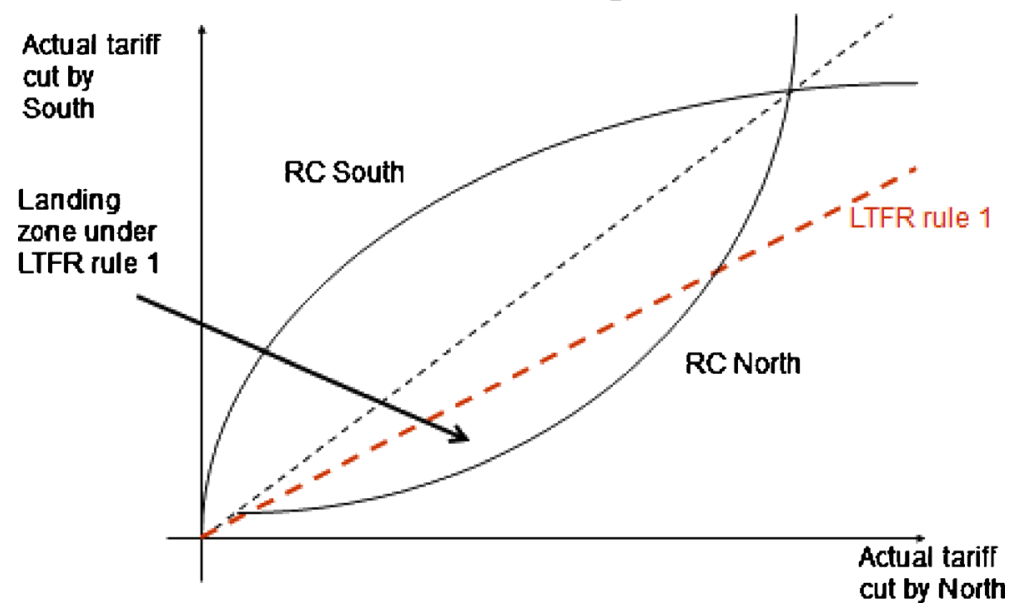

Fig. 5 Combine ratification constraints and LTFR: a restricted landing zone 


\section{An impasse can result with certain LTFR rules}

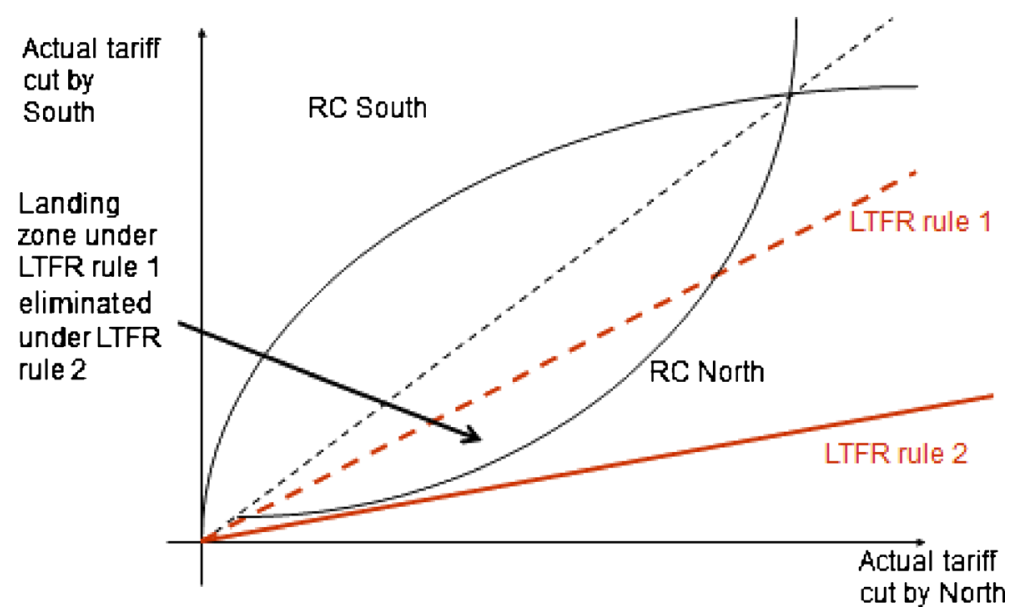

Fig. 6 An impasse can result with certain LTFR rules

began to assert its interests more publicly. The diminished stature of the Ministry of Foreign Commerce in the Chinese government in the years following accession to the WTO was also said to give line ministry and sectoral ministries greater clout in Beijing.

These factors tighten the ratification constraints in the North and the South so as to reduce the set of potentially acceptable tariff cutting deals, as shown in Fig. 7.

\section{Faster export growth during the Doha Round era than before}

The acceleration of China's rate of economic growth, and later that of India's, in the years running up to the global financial crisis added to world economic growth and to world trade. These emerging markets were not alone in experiencing faster rates of

\section{Greater domestic opposition to trade reform and the ratification constraint}

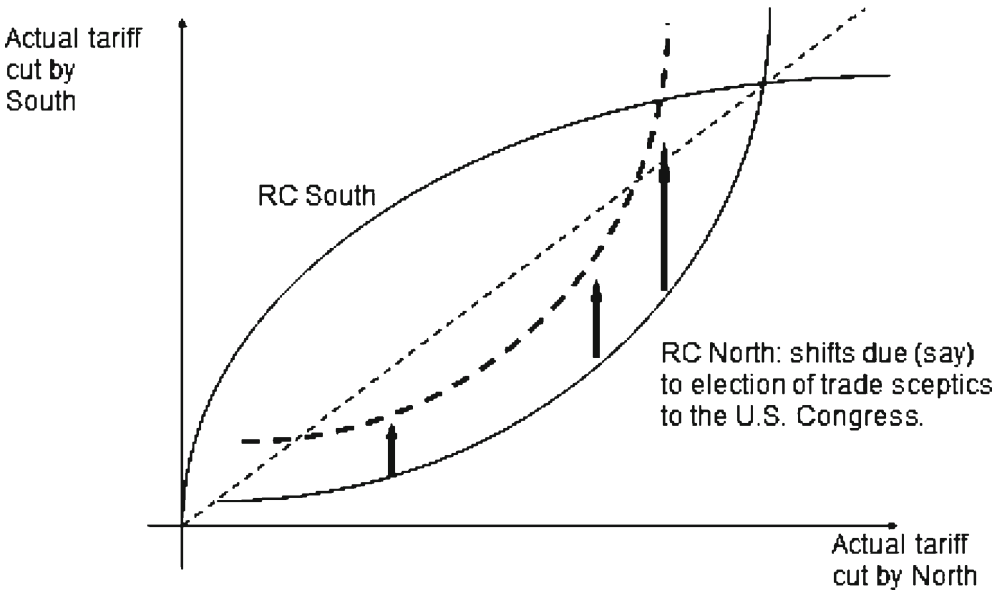

Fig. 7 Greater domestic opposition to trade reform and the ratification constraint 


\section{Faster export growth independent of the DDA contracts the landing zone}

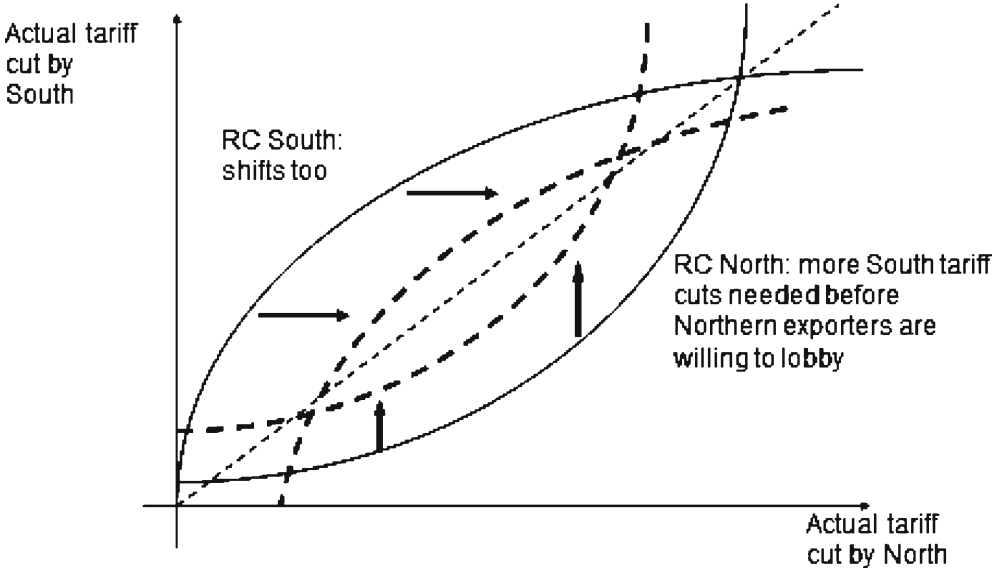

Fig. 8 Faster export growth independent of the DDA contracts the landing zone

economic growth, creating export opportunities for trading partners. The result was that for many jurisdictions - including the European Union, the Least Developed group of countries, as well as China and India - their exports grew at a quicker pace during the pre-crisis years of the Doha Round than during the earlier Uruguay Round. For example, from 2001 to 2007 EU exports grew on average $12 \%$ per annum, compared to falling $2 \%$ per annum during the Uruguay Round. The only large jurisdiction for which this was not the case was the United States, which may account in part for the persistence with which it has advocated a Doha Round outcome that results in substantial trade reform.

The faster rates of non-Doha-related export growth affected the value of the "no deal" status quo in the eyes of political decision makers. What is not denied is that successful completion of the Doha Round is likely to have raised export growth rates. But decision makers may be tempted to ask whether increasing the annual rate of exports from 12 to $13 \%$, for example, provides much political payoff compared to the likely opposition to a trade deal. Moreover exporters, that typically lobby for trade deals may find it difficult enough to supply existing orders during such a boom and so place a lower value on the additional exports that a trade deal brings. ${ }^{20}$ In sum, the willingness of exporters and the like to lobby may be conditional on the underlying rate of growth of overseas sales. If so, the pre-crisis global boom may have made finding a landing zone for the Doha Round more difficult, as portrayed in Fig. 8.

\section{Unilateral trade reform and the negotiating currency of the Doha Round}

The negotiating currency of the WTO relates specifically to bindings. Governments negotiate the maximum levels of tariffs than can be imposed on imported manufactured goods and the maximum tariffs, quotas, and subsidies that can be employed in national

\footnotetext{
${ }^{20}$ For what it is worth, in a 2005 meeting with the Swiss Federal Counsellor responsible for trade policy I made this point and was immediately, and unexpectedly, supported by the representative of the largest group of Swiss exporters.
} 
Table 1 Except China, large emerging markets have large "binding overhangs"

\begin{tabular}{lllll}
\hline Rank & Country & $\begin{array}{l}\text { Mean bound tariff rate on } \\
\text { NAMA (\%) }\end{array}$ & $\begin{array}{l}\text { Mean applied tariff rate on } \\
\text { NAMA (\%) }\end{array}$ & $\begin{array}{l}\text { Cut needed to create business } \\
\text { opportunities }\end{array}$ \\
\hline 1. & China & 9.1 & 9.1 & 0.00 \\
2. & India & 36.2 & 11.5 & 68.2 \\
3. & Mexico & 34.9 & 11.2 & 67.9 \\
4. & Brazil & 30.8 & 12.5 & 59.4 \\
5. & Turkey & 16.9 & 4.8 & 71.6 \\
\hline
\end{tabular}

Source: WTO Trade Profiles, April 2008

agricultural policy. WTO rules do not prevent a government from setting a policy instrument below the maximum allowable level.

Indeed, differences between the maximum bound and the applied levels are so common that they are referred to as a "binding overhang." The extent of the binding overhang on tariffs on manufactured goods for the five largest developing economies is reported in Table 1. Except for China, by 2008 the other large emerging markets set average applied tariff rates well below the maximum allowable levels.

What is the significance of such binding overhangs for the Doha Round of trade negotiations? In principle, agreements to cut bindings need not result in applied tariffs being cut. For example, the halving of a bound tariff rate of $20 \%$ will not automatically result in a cut in the applied tariff if the latter is $10 \%$ or less. The reduction in the bound rate is valuable to foreign commercial interests if they attach a positive probability to the applied tariff ever being raised above the new, lower bound tariff rate. It is for this reason that many economic analysts ${ }^{21}$ have pointed to the uncertainty-reducing benefits of cutting tariff bindings (as well as the traditional benefits that arise when bound rates are cut below prevailing applied tariff rates.)

During the Doha Round several factors have come together than have undermined this logic. First, unilateral cuts by developing countries in tariffs on imported manufactures as well as unilateral subsidy cuts for farmers by the EU and the US have been extensive, in turn creating substantial binding overhangs. Second, the existing binding overhangs in manufacturing and agriculture are so large that in many cases they exceed the proposed Doha Round cuts in bindings.

Third, US and EU exporters have repeatedly stated that they place little or no value on cuts in bindings that do not cut applied tariff rates (Young 2010; Schwab 2011). ${ }^{22}$

\footnotetext{
${ }^{21}$ In this regard Messerlin (2008) addresses the benefits of binding trade policies in the context of a Doha Round deal.

22 The difference between bound and applied rates of tariffs is explicitly referred to in the position papers of leading industrial trade groups on liberalizing manufactured goods trade. For example, in a paper dated January 2010 the US National Association of Manufacturers stated
}

The Doha Round would cut the tariffs of the advanced developing countries somewhere between $1 / 8$ and $1 / 10$ - not insignificant but not likely to generate large new trade flows. This is particularly the case since the tariff cuts will come from the higher official "bound" rates and in many cases these cuts will not equal the applied rates for up to 10 years. In the meantime U.S. exporters will see little benefit.

This position note included charts for China, India, and Brazil purporting to show the intertemporal path of actual and bound tariffs should prevailing Doha Round tariff proposals be implemented. This position paper can be accessed at http://www.nam.org/ /media/C41A4C1BC77741D8826AA40DFEF66AB1/NAM_ Position_on_the_Doha_Round.pdf 
Implicitly, these lobbies discount the possibility that the unilateral tariff reforms of the larger developing countries will be reversed. Influential US legislators have called for cuts in applied tariff rates, specifically pointing out that bound tariff cuts are not enough (see, for example, Grassley 2007). Fourth, leading developing countries have stated that they will not "pay" for unilateral reductions in subsidies to industrial country farmers, arguing that those subsidies were illegitimate in the first place. ${ }^{23}$ In short, neither the North nor the South are willing to pay for the other's unilateral reforms.

How can this be analyzed in the framework developed here? Recall, the ratification constraints are defined in terms of actual tariff cuts. To translate the minimum actual tariff cut by a trading partner into the minimum binding tariff cut, one must add the size of the binding overhang of the trading partner. Therefore, if the North requires the South to cut its applied tariffs by at least $3 \%$ and the existing tariff binding overhang in the South is $5 \%$, then the North must demand that the South will cut its bound rate by the sum, namely, $8 \%$. Graphically, this amounts to vertically translating the North's ratification constraint by the size of the current binding overhang in the South, as shown in Fig. 9. A similar (in this case rightward translation) of the South's ratification constraint is necessary when there exists a Northern binding overhang (as there is in agricultural subsidies.)

The effect of shifting up the North's ratification constraint is to reduce the set of possible trade deals that satisfy both the binding-adjusted ratification constraint and the LTFR rule. The significance of Fig. 9 is that it shows how domestic political constraints interact with two well-known features of the Doha Round (binding overhang and the LTFR negotiating principle) so as to reduce the set of possible mutually acceptable Doha Round outcomes.

Moreover, every time the South engages in unilateral trade reform (and many developing countries have done so during the Doha Round), then this induces the North to ratchet up its negotiating demands. As Fig. 10 shows, the process of unilateral trade reform in the South can go so far that no mutually acceptable Doha Round deal is possible-an impasse results. In this case, the combination of unilateral trade reform and bindings being the negotiating currency of the WTO create a stumbling block for multilateral trade reform. Taking account of this central feature of the WTO system effectively introduces a tension between two forms of trade reform that many economists have usually supported without reservation.

It is worth stressing here that this outcome is not the "fault" of Southern unilateral tariff reform. Bearing in mind that unilateral reform of agricultural subsidies has occurred as well, the problem here is the unwillingness of the North and the South to

\footnotetext{
${ }^{23}$ For example, in 2007 the Indian Minister of Commerce stated "I do hope that the US moves forward in addressing the issue of domestic support, domestic subsidies because you cannot be talking of fair trade and continue with domestic subsidies." See http://www.indianexpress.com/news/us-should-be-open-to-farmsubsidy-cuts-kamal-nath/33970. Another news report on deliberations in June 2007 stated that "Kamal Nath, the Indian trade minister, said the United States had offered to cap its domestic agricultural subsidies at $\$ 17$ billion, considerably lower than the $\$ 22$ billion it had offered before, but still well above the roughly $\$ 11$ billion that American farmers are currently receiving. Nath said that offer had "no logic or equity," a point his Brazilian counterpart, Celso Amorim, echoed." See http://www.nytimes.com/2007/06/21/business/ worldbusiness/21iht-wto.4.6264066.html? r=0. Another news report making specific reference to binding and applied subsidy levels of the United States can be found at http://www.domain-b.com/economy/trade/ 20080723 kamal_nath.html
} 


\section{Combining the effects of unilateral tariff reform and the LTFR rule}

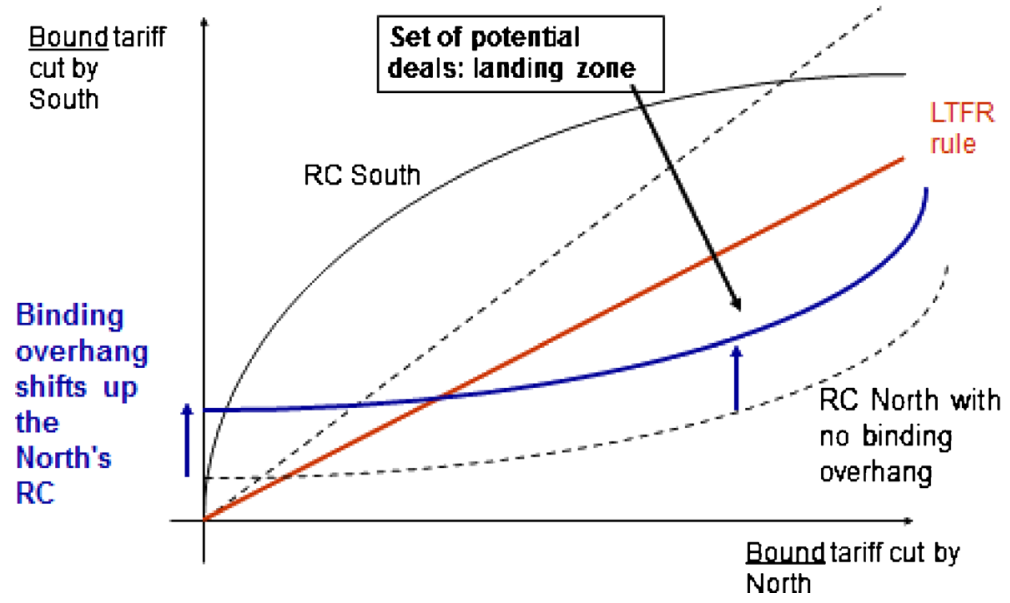

Fig. 9 Combining the effects of unilateral tariff reform and the LTFR rule

"pay" for each other's unilateral trade reforms-effectively denying the uncertaintyreducing value of lowered bindings.

\section{China's accession to the WTO, subsequent export growth, and intra-South dynamics}

In recent years some analysts have contended that the fast growth of Chinese exports since that country joined the WTO in 2001 have cast a shadow over the Doha Round negotiations (Wolfe 2013). It has been argued that some developing countries are reluctant to cut tariffs on imported manufactured goods in the context of a WTO agreement because,

\section{Unilateral tariff reform plus LTFR rule as a stumbling block}

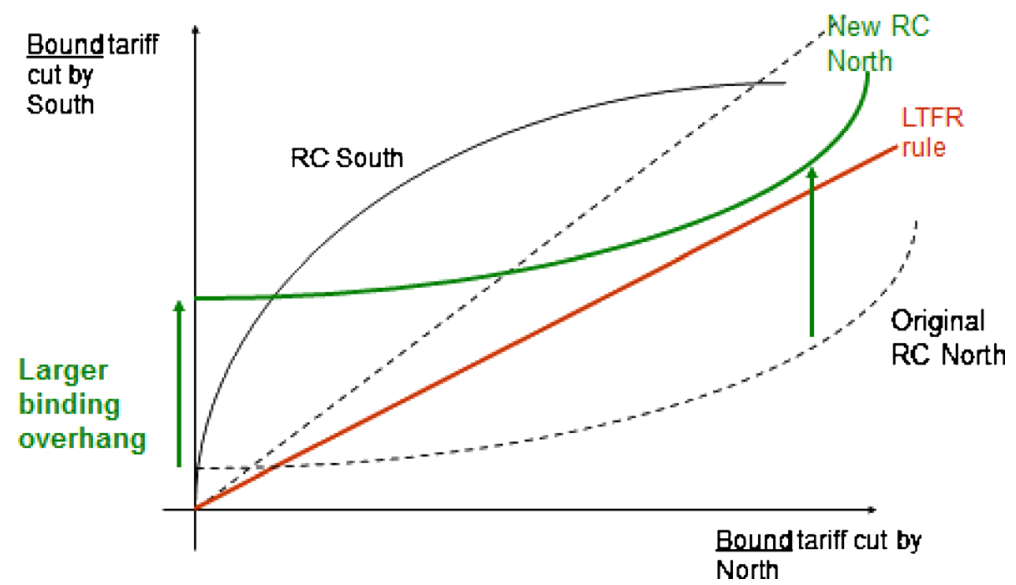

Fig. 10 Unilateral tariff reform plus LTFR rule as a stumbling block 


\section{Unanticipated improvements in Chinese competitiveness may tighten ratification constraints}

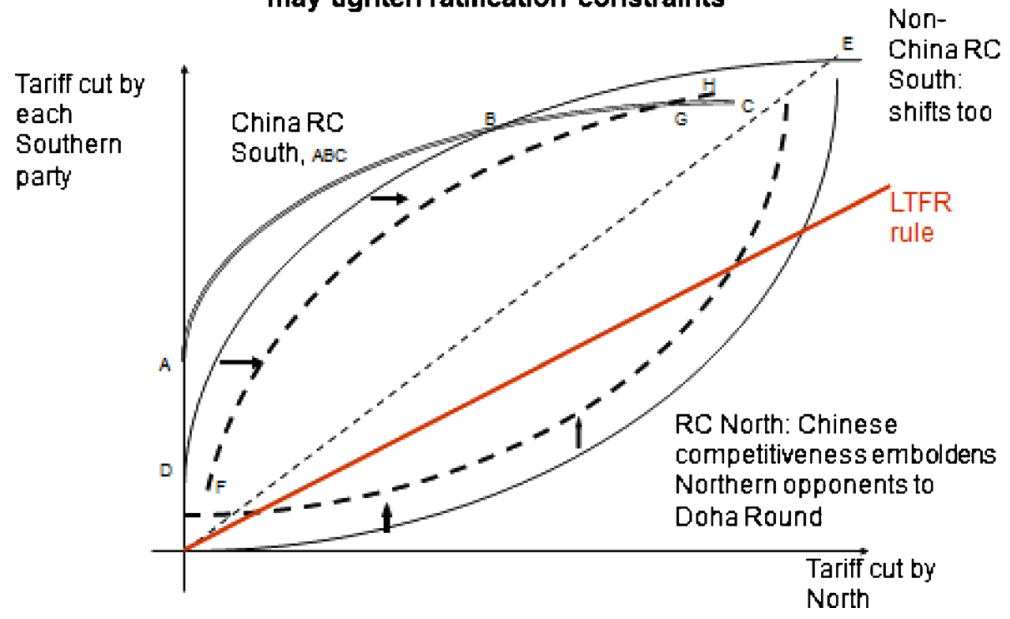

Fig. 11 Unanticipated improvements in Chinese competitiveness may tighten ratification constraints

according to the Most Favored Nation principle, such market opening must be extended to all WTO members, including China. On this view, intra-South dynamics are said to be important not only North-South dynamics (Donnan 2013).

To explore these matters the framework developed in the previous sections must be modified. The simplest way to do so is to assume the South comprises two developing countries (China and non-China), each with their own ratification constraint. ${ }^{24}$ Ratification by the South requires the assent of both developing countries and so the South's ratification constraint is given by the lower envelope of ratification constraints of the countries that comprise it. In Fig. 11 the Chinese and non-Chinese ratification constraints are given by ABC and DBE, respectively. The South's ratification constraint is the lower envelope of these two constraints, given by DBC. For the moment the Northern ratification constraint is unchanged.

Now consider the impact of an unanticipated increase in Chinese export competitiveness. To the extent that greater import competition reduces the number of domestic firms and the profitability of surviving firms, the rise of China could in principle reduce the political clout of import-competing interests and relax ratification constraints in the North and in the non-China South. In some cases this could result in a landing zone being created where previously there had been an impasse. This, however, is not the only logical possibility.

Unanticipated increases in Chinese export competitiveness could embolden opponents to multilateral trade liberalization that seek to keep as much protection against Chinese imports as possible. These opponents may argue that since further increases in Chinese competitiveness cannot be ruled out, that the option to impose protection is valuable, even if it is never exercised. Ratification constraints in the North and non-

\footnotetext{
${ }^{24}$ To fix ideas assume that the tariff cut by China and the non-Chinese country in the South are the same, reflecting their shared status as developing countries. Therefore, like before, an agreement is a pair of tariff cuts, one for the North and one for the South, that satisfies every ratification constraint and the LTFR rule. An obvious extension is to allow for different tariff cuts by China and the non-Chinese developing country. In which case, each ratification constraint would be a function of three tariff cuts.
} 


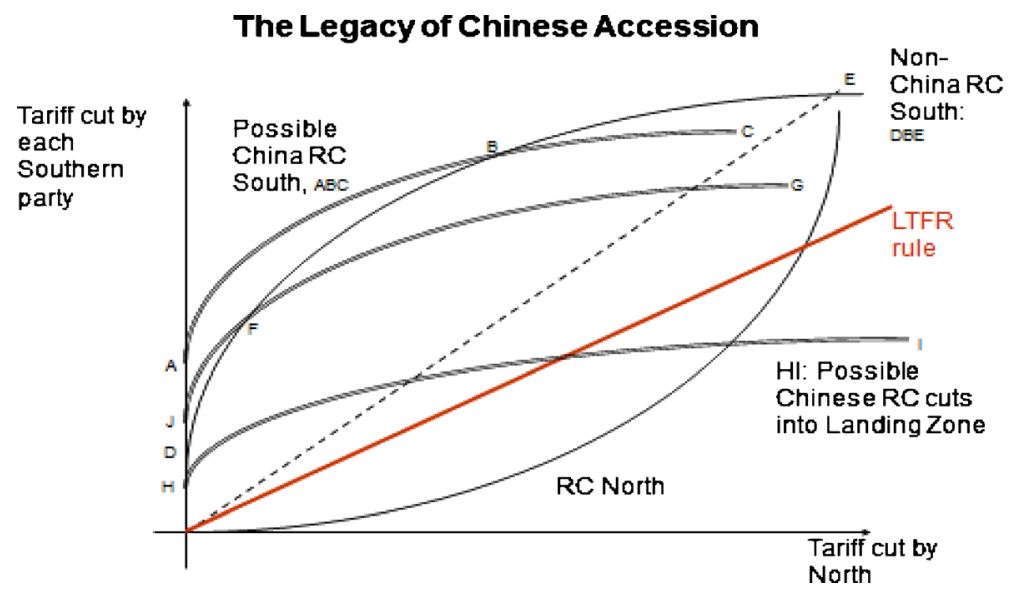

Fig. 12 The legacy of Chinese accession

Chinese South may then tighten. In Fig. 11 this amounts to the non-Chinese South's ratification constraint shifting from $\mathrm{DBE}$ to $\mathrm{FGH}$, causing the South's overall ratification constraint to shift to FGC. The North's ratification constraint shifts up too, reducing any landing zone. So long as the new ratification constraint of the South lies above the Full Reciprocity line (the $45^{\circ}$ line) then it will be the shift in the North's ratification constraint that matters, intersecting as it does with the LTFR rule. In this case the intra-South dynamics caused by the Chinese export juggernaut would not create a Doha Round impasse. Nor must unexpected improvements in Chinese competitiveness result in an impasse for its consequence could be to reduce the landing zone, not necessarily to eliminate that zone.

Another argument made concerning the Doha Round deadlock is that China believes the terms of its WTO accession were so onerous that, for all intensive purposes, the implementation of those accession terms is its contribution to the Doha Round.

\section{Alternative LTFR Rules: Non-reciprocity could take many forms}

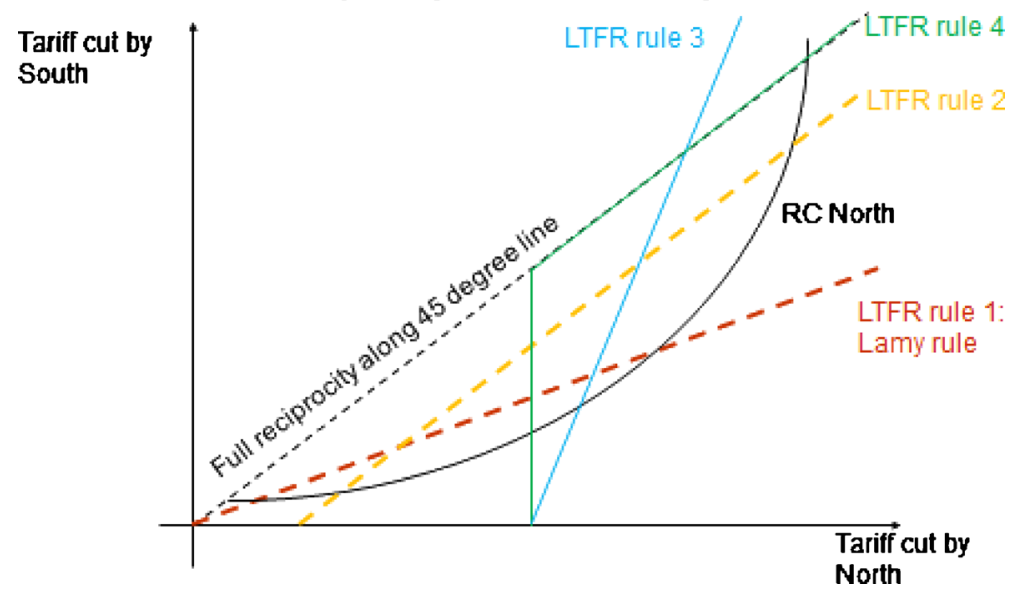

Fig. 13 Alternative LTFR rules: non-reciprocity could take many forms 
Suppose attitudes hardened in Beijing and Chinese unwillingness to liberalize in the context of the Doha Round became apparent. In Fig. 12 this would be represented by a shift in the Chinese ratification constraint from ABC to JFG, effectively shifting down the overall South's ratification constraint from DBC to DFG, a change that in this case would not result in an impasse. Even if the Chinese ratification constraint shifted down to $\mathrm{HI}$, then this would reduce the size of the landing zone but not eliminate it.

As Figs. 11 and 12 show, it is difficult to see how splits within the developing countries alone are responsible for the Doha Round impasse. However, the combination of those splits and other factors that markedly increase the negotiating demands of the North (some of which have been identified in earlier sections) could account for a Doha Round impasse.

\section{Concluding remarks}

Apart from the impact of the Great Recession, the failure to complete the Doha Round of multilateral trade negotiations is probably the most significant event in the world trading system during the past 10 years. Unless negotiations can be concluded successfully, the set of accords covered by WTO dispute settlement will not expand. Moreover, trade policy analysts are divided as to how much traffic the Dispute Settlement Understanding of the WTO can bear before inducing a backlash from member governments. Understanding why the Doha Round impasse arose is important - yet there are few analyses available to guide our thinking.

In this paper I developed a simple framework that brings together a number of the features associated with the Doha Round, grounding the analysis in a traditional twostage negotiation-and-ratification set up. Doha Round impasses are possible under a number of different situations. Each feature is represented graphically in a single diagram, allowing for the interaction between different factors to be examined. More generally, this paper adds to the small number of analyses of deadlocks in international negotiations (Odell 2009; Narlikar 2010; Elsig and Dupont 2011). Having said this, it would be churlish to claim that every potential contributor to the Doha impasse mentioned in the commentary of recent years has been assessed here. Clearly more analysis is needed. ${ }^{25}$

It cannot be denied that in seeking to analyze the Doha Round impasse in a twodimensional diagram some potentially relevant features have been suppressed. Explicit modelling choices were made here. For example, the focus on a single index of trade reform (which for labelling purposes were referred to as tariffs) does not allow trade-offs between trade policy instruments to be considered. Moreover, some might prefer that the ratification constraints be derived from an underlying political economy model of trade policy, with a tug of war between different interest groups and possibly different sectors. What matters in this analysis is that such a ratification constraint exists and is monotonic. These observations, however, indicate where extensions might be developed.

\footnotetext{
${ }^{25}$ I have applied the same framework to events or initiatives that might break the Doha Round impasse, including the inclusion of a special safeguard mechanism for agricultural trade, a severe recession in the North, and the conclusion of a substantial agreement to liberalize trade in services. Details are available upon request.
} 
Perhaps the most important finding is that, as feature after feature is added to the analysis, the size of the landing zone (representing the set of mutually acceptable Doha Round outcomes) contracts and, in some cases, an impasse results. Such a finding casts doubt on any one factor being solely responsible for the failure to conclude the Doha Development Agenda.

Arguably some of these factors were not known in 2001 when the Doha Round was launched, therefore putting all the blame on poor design is probably inappropriate. That subsequent events could have contributed to the impasse highlights the role of contingency in determining the success of international negotiations. Incidentally, such contingency begs the question as to the degree to which prior GATT and WTO successes were due to extraneous political and economic dynamics?

The analysis developed here raises further questions for officials and policy-oriented analysts. The first matter to be considered is, assuming that the objective of tilting the Doha Round negotiation to the benefit of developing countries is to be retained, are there alternative Less Than Full Reciprocity rules that meet this objective without reducing the landing zone that much? Figure 13 presents alternatives to the LTFR rule considered in this paper. The three alternatives portrayed differ, yet each is predicated upon a minimum degree of Northern trade reform. Questions of this type are partly normative, so the likelihood of reaching an agreement should not be the only evaluation criteria.

The potential tension between unilateral trade reform and multilateral trade reform deserves further thought. As argued above, the argument is not that the tension always exists. However, so long as the reduction in bindings are not valued in their own right, and binding overhangs of the current magnitude remain, then negotiating a mutually acceptable Doha Round deal remains a distant prospect. In the absence of substantial reversals of unilateral trade reform, perhaps this spells the end of the road for WTO negotiations on agriculture and manufacturing. If so, should the emphasis shift to expanding the remit of the WTO rules? Or should the focus become negotiating further service sector reforms? Or ought the often-asserted view of the limited gains from binding prior unilateral trade reforms be subject to greater scrutiny?

\section{References}

Ackerman, F., \& Gallagher, K. (2008). The shrinking gains from global trade liberalization in computable general equilibrium models: a critical assessment. International Journal of Political Economy, 37(1), 50-77.

Aldonas, G. (2007). What would we bargain for if development really mattered? Arizona Journal of International and Comparative Law, 24(1), 29-39.

Anderson, K., Valenzuela, E., \& van der Mensbrugghe, D. (2009)."Welfare and Poverty Effects of Global Agricultural and Trade Policies Using the Linkage Model." Working paper 52785. World Bank.

Bagwell, K., \& Staiger, R. W. (2012) "Can the Doha round be a development round? Setting A Place at the Table." 15 October.

Bhagwati, J., \& Sutherland, P. (2011). The Doha Round: Setting a Deadline; Defining a Final Deal. Interim Report. January.

Blustein, P. (2009). Misadventures of the most favored nations. New York: Public Affairs.

Decreux, Y., \& Fontagné, L. (2011). "Economic impact of potential outcomes of the DDA." CEPII working paper 2011-23.

Destler, I. M. D. (2005). American trade politics (4th ed.). Washington, DC: Peterson Institute for International Economics.

Donnan, S. (2013). "Bali talks set to showcase new dynamics in the WTO," Financial Times. 29 November. Elsig, M., \& Dupont, C. (2011). "Persistent deadlock in multilateral trade negotiations: The case of Doha." Mimeo. Graduate Institute and World Trade Institute. 
Evenett, S. J., \& Meier, M. (2006). “The US Congressional Elections in 2006: What Implications for US Trade Policy?" Mimeo. Swiss Institute for International Economics and Applied Economic Research. University of St. Gallen. 9 November.

Harbinson, S. (2012). “The WTO must bounce back.” ECIPE Policy Briefs no. 09/12. Brussels.

Hoekman, B. M. (2008). The general agreement on trade in services: doomed to fail? does it matter? Journal of Industry, Competition, and Trade, 8, 295-318.

Hufbauer, G. C., \& Schott, J. J. (2012a). Will the WTO Enjoy a Bright Future? Policy Brief 12-11 (May). Washington: Peterson Institute for International Economics.

Hufbauer, G. C., \& Schott, J. (2012b). Payoff from the World Trade Agenda 2013. Report to the ICC Foundation, Peterson Institute of International Economics. December.

Hufbauer, G. C., Schott, J. J., \& Wong, W. F. (2010). Figuring Out the Doha Round. Policy Analyses in International Economics 91. Washington: Peterson Institute for International Economics.

International Monetary Fund (IMF) (2011). "The WTO Doha Trade Round-Unlocking the Negotiations and Beyond." Strategy, Policy, and Review Department. November.

Ismail, F. (2012). "Is the Doha Round dead? What is the way forward?" BWPI working paper 167. University of Manchester. May.

Lamy, P. (2008). Speech to the Annual 2008 Session of the Parliamentary Conference of the WTO. Geneva. 11 September. Available at http://www.wto.org/english/news_e/sppl_e/sppl99_e.htm.

Martin, W., \& Mattoo, A. (eds.) (2011). Unfinished business? The WTO's Doha Agenda. World Bank.

Messerlin, P. (2008). "Walking a tightrope. World trade in manufacturing and the benefits of binding." Science Po. June.

Narlikar, A. (ed.) (2010). Deadlocks in multilateral negotiations: Cases and solutions. Cambridge University Press.

Odell, J. (2009). Breaking deadlocks in international institutional negotiations: the WTO, Seattle, and Doha. International Studies Quarterly, 53(2), 273-299.

Page, S., Cali, M., \& te Velde, D. W. (2008). "Development package at the WTO? What do developing countries want from the Doha Round?” Overseas Development Institute. 17 July.

Putnam, R. (1988). Diplomacy and domestic politics: the logic of two-level games. International Organization, 42(3), 427-460.

Schwab, S. (2011). "After Doha: Why the negotiations are doomed and what we should do about it." Foreign Affairs. May/June.

Tarullo, D. K. (2006). "The end of the big trade deal. Why Doha will be the last of the grand multilateral trade negotiations." The International Economy. Summer, 45-49.

Wolfe, R. (2007). "Can the trading system be governed? Institutional Implications of the WTO's Suspended Animation." CIGI Working Paper no. 30. September.

Wolfe, R. (2009a). "The special safeguard fiasco in the WTO: The perils of inadequate analysis and negotiation." Group d'Economie Mondiale working paper, Science Po. 10 February.

Wolfe, R. (2009b). "Sprinting during a Marathon: Why the WTO Ministerial failed in July 2008." Group d'Economie Mondiale working paper, Science Po. April.

Wolfe, R. (2013). "First diagnose, then treat: what ails the Doha round?" Mimeo. European Institute Florence. 26 November.

Young, A. R. (2010). "Transatlantic intransigence in the Doha Round: domestic politics and the difficulty of compromise." Chapter 5 in Amrita Narlika (ed). Deadlocks in Multilateral Negotiations: Cases and Solutions. Cambridge University Press. 